\title{
ANALISIS KEMAMPUAN PEMECAHAN MASALAH MATEMATIK PESERTA DIDIK MENURUT TEORI JOHN DEWEY DITINJAU DARI GAYA BELAJAR
}

\author{
Neny Yunaeti, Ebih AR Arhasy, Nani Ratnaningsih \\ Universitas Siliwangi, Jln. Siliwangi No. 24, Tasikmalaya 46115, Jawa Barat, Indonesia \\ Email: nenyunaeti@gmail.com
}

\begin{abstract}
Abstrak
Tujuan penelitian ini adalah menganalisis dan mendeskripsikan kemampuan pemecahan masalah matematik peserta didik menurut teori John Dewey ditinjau dari 3 gaya belajar yaitu visual, auditorial, dan kinestetik. Metode penelitian yang digunakan merupakan penelitian kualitatif eksploratif. Subjek penelitian diambil sebanyak 3 siswa yang masing-masing mewakili 3 tipe gaya belajar. Teknik pengumpulan data metode think aloud. Instrumen yang digunakan meliputi peneliti sendiri sebagai instrumen utama yang dibantu dengan tes pemecahan masalah matematik, angket gaya belajar, dan wawancara tidak terstruktur. Berdasarkan analisis data diperoleh simpulan: kemampuan pemecahan masalah matematik materi perbandingan trigonometri peserta didik yang bergaya belajar visual, auditorial dan kinestetik memiliki kemampuan menyampaikan argumentasi verbal, mengidentifikasi fakta, melakukan perhitungan dalam menyelesaikan masalah, membandingkan jawaban yang didapat dengan perhitungan yang lain, dan memilih strategi yang tepat setelah melakukan percobaan strategi yang lain.
\end{abstract}

Kata kunci: pemecahan masalah matematik menurut John Dewey, gaya belajar.

\begin{abstract}
The purpose of this study was to analyze and describe the mathematical problem-solving abilities of students according to John Dewey's theory in terms of 3 learning styles, namely visual, auditory, and kinesthetic. The research method used is qualitative exploratory research. The research subjects were taken as many as three students, each representing three types of learning styles. The data collection technique is a think-aloud method. The instruments used include the researcher himself as the main instrument assisted by mathematical problem-solving tests, learning style questionnaires, and unstructured interviews. Based on the data analysis, the conclusion is: the ability to solve mathematical problems in the material of trigonometric comparison of students with visual, auditory, and kinesthetic learning styles can convey verbal arguments, identify facts, perform calculations in solving problems, compare the answers obtained with other calculations, and choose strategies right after experimenting with other strategies.
\end{abstract}

Keywords: mathematical problem solving according to John Dewey, learning style

\section{Pendahuluan}

Matematika memiliki peranan penting dalam kehidupan sehari-hari, terutama untuk mendukung perkembangan ilmu pengetahuan dan teknologi. Hal ini karena melalui belajar matematika peserta didik dapat mengembangkan kemampuan berpikir logis, analitis, kritis, dan kreatif secara cermat dan objektif dalam menyelesaikan masalah. 
Selain itu, dalam pembelajaran matematika peserta didik akan mengenal hubungan dan pola generalisasi pengalaman, sehingga mereka dapat meningkatkan kreativitas dan kesadarannya terhadap perkembangan sosial budaya masyarakat [1]. Hal tersebut sejalan dengan tujuan pembelajaran matematika yang terdapat dalam Kurikulum 2013 tentang pembelajaran saintifik yaitu: 1) meningkatkan kemampuan intelektual, khususnya kemampuan berpikir tingkat tinggi, 2) membentuk kemampuan peserta didik dalam menyelesaikan suatu masalah secara sistematis, 3) memperoleh hasil belajar yang maksimal, 4) melatih peserta didik dalam mengkomunikasikan ide-ide, khususnya dalam menulis karya ilmiah, dan 5) mengembangkan karakter peserta didik [2]. Salah satu kemampuan yang harus dikuasai peserta didik melalui pembelajaran matematika adalah pemecahan masalah matematik. Menurut Aljaberi [3], pemecahan masalah dianggap sebagai salah satu kegiatan kognitif yang penting digunakan dalam kehidupan sehari-hari, dan pemecahan masalah matematik dianggap sebagai bagian terpenting dalam bidang matematika.

Branca [4] menegaskan pentingnya kemampuan pemecahan masalah oleh peserta didik dalam matematika terdiri dari: (1) kemampuan menyelesaikan masalah merupakan tujuan umum pengajaran matematika, bahkan sebagai jantungnya matematika, (2) pemecahan masalah yang meliputi metode, prosedur dan strategi merupakan proses inti dan utama dalam kurikulum matematika, dan (3) penyelesaian masalah merupakan kemampuan dasar dalam belajar matematika. Kemampuan pemecahan masalah sangat penting dalam proses pembelajaran, maupun dalam kehidupan sehari-hari. Pemecahan masalah sebagai langkah awal peserta didik dalam mengembangkan ide-ide dalam membangun pengetahuan baru dan mengembangkan keterampilan-keterampilan matematika. Seperti yang diungkap dalam NCTM [5] bahwa semua peserta didik harus membangun pengetahuan matematika baru melalui pemecahan masalah. Hal ini dikarenakan dalam proses pemecahan masalah, peserta didik dapat berusaha untuk belajar mengenai konsep yang belum diketahui sehingga peserta didik dapat menjadikan pembelajaran tersebut sebagai pengalaman belajar selanjutnya dengan masalah atau soal dengan bobot sama. Dari beberapa pendapat di atas, dapat disimpulkan bahwa kemampuan pemecahan masalah sangat berperan penting dalam pembelajaran.

Sayangnya, hasil tes PISA (Programme for International Student Assesment) 2015 kemampuan pemecahan masalah peserta didik Indonesia masih rendah [6]. Dari hasil tes dan evaluasi PISA 2015, berturut-turut rata-rata skor pencapaian siswa-siswi Indonesia untuk sains, membaca, dan matematika berada di peringkat 62, 61, dan 63 dari 69 negara yang dievaluasi. Ini berarti peserta didik yang mampu memecahkan masalah dengan strategi dan prosedur yang benar masih tergolong rendah. Hal ini diasumsikan karena karakter soal PISA pada umumnya sifatnya pemecahan masalah.

Penelitian yang membahas mengenai kemampuan pemecahan masalah matematik siswa sudah bukan hal baru untuk diteliti, termasuk yang melibatkan gaya belajar siswa, diantaranya penelitian yang dilakukan Ariansyah [7], Awaliyah [8], dan Syaharuddin [9]. Tetapi penelitian ini berbeda dengan penelitian yang sudah 
dilakukan sebelumnya. Penelitian sebelumnya meneliti kemampuan pemecahan masalah matematik berdasarkan langkah-langkah Polya di tinjau dari gaya belajar, sedangkan penelitian ini menganalisis kemampuan pemecahan masalah matematik berdasarkan langkah-langkah John Dewey dan ditinjau dari gaya belajar Deporter \& Hernacki yaitu gaya belajar visual, gaya belajar auditorial, gaya belajar kinestetik. Tahap - tahap pemecahan masalah menurut Dewey [9 - 14] memiliki lima tahapan yaitu: Mengenali masalah (confront problem), mendefinisikan masalah (diagnose or define problem), penemuan solusi (inventory several solution), menguji beberapa ide (conjecture consequences of solutions), dan mengambil hipotesis terbaik (test consequences).

Berdasarkan wawancara dengan guru mata pelajaran matematika kelas $\mathrm{X}$ Akuntansi dan Keuangan Lembaga SMKN 1 Banjar, ternyata masih banyak peserta didik yang mengalami kesulitan dalam mengerjakan soal trigonometri terutama pada penggunaan perbandingan trigonometri. Adapun kesulitan yang dihadapi diantaranya kesulitan dalam menentukan data apa yang harus digunakan oleh peserta didik dalam pengerjaan yang sistematis, sehingga banyak kesalahan yang dilakukan. Kita ketahui bersama bahwa penggunaan perbandingan trigonometri secara benar itu penting dalam pembelajaran matematika karena menuntut peserta didik untuk dapat berpikir secara kritis, logis, sistematis dan teliti, yang mana hal ini dapat menjadi landasan bagi siswa untuk membangun pola pikir yang baik dalam pemecahan masalah matematik. Hasil penelitian Andriani, Suastika, \& Sesanti [15] juga mengungkapkan bahwa masih banyak peserta didik yang tidak dapat menyelesaikan soal pemecahan masalah matematik pada materi perbandingan trigonometri. Berdasarkan uraian di atas peneliti tertarik untuk melakukan penelitian berjudul "Analisis Kemampuan Pemecahan Masalah Matematik Peserta Didik Menurut John Dewey Ditinjau dari Gaya Belajar Peserta Didik".

\section{Metode}

Metode penelitian yang digunakan dalam penelitian ini merupakan metode penelitian kualitatif eksploratif. Menurut Sugiyono [16] Metode penelitian kualitatif eksploratif adalah penelitian yang bertujuan untuk memaparkan suatu objek secara relatif mendalam atau dengan kata lain penelitian eksploratif adalah penelitian yang dilakukan untuk mencari sebab atau hal-hal yang mempengaruhi terjadinya sesuatu dan dipakai manakala kita belum mengetahui secara persis dan specifik mengenai objek penelitian kita. Peneliti mengungkapkan penelitian eksploratif ini secara kualitatif. Pada penelitian ini menggali, memaparkan atau menganalisis dan mendeskripsikan kemampuan pemecahan masalah matematik peserta didik yang mempunyai gaya belajar visual, gaya belajar auditorial, dan gaya belajar kinestetik dalam menyelesaikan masalah perbandingan trigonometri.

Teknik pengumpulan data pada penelitian ini menggunakan think aloud. Teknik think aloud dilakukan dengan meminta subjek penelitian untuk menyelesaikan tes pemecahan masalah sekaligus proses berpikirnya diungkapkan secara lisan [17]. Think aloud pada penelitian ini yaitu peserta didik mengungkapkan ide-ide yang

JARME, Volume 3, No. 1, Januari 2021, 10 - 21. 
dipikirkan menggunakan kalimat verbal atau diucapkan dalam proses pemecahkan masalah matematik sehingga data yang didapat kata-kata lisan dan kata-kata tertulis.

Langkah dalam menentukan subjek penelitian yaitu semua peserta didik kelas X Akuntansi dan Keuangan Lembaga 1 sebanyak 36 peserta didik secara bergantian diberikan tes kemampuan pemecahan masalah matematik pada mataeri perbandingan trigonometri dengan teknik think aloud supaya pada waktu peserta didik mengerjakan soal kemampuan pemecahan masalah matematik dapat diketahui proses berpikirnya. Dari langkah tersebut didapatkan 11 peserta didik yang dapat menyelesaikan soal kemampuan pemecahan masalah matematik. Semua peserta didik yang dapat menyelesaikan soal kemampuan pemecahan masalah matematik diberikan angket gaya belajar untuk dikategorikan ke gaya belajar visual, gaya belajar auditorial, dan gaya belajar kinestetik. Dari proses tersebut didapatkan data yang memiliki gaya belajar visual sebanyak 5 orang, gaya belajar auditorial 4 orang, dan gaya belajar kinestetik 2 orang.

Dari setiap gaya belajar, satu peserta didik diambil untuk diwawancara tidak terstruktur secara berurutan dimulai dari yang memperoleh skor paling tinggi untuk mendapatkan informasi mengenai kemampuan pemecahan masalah matematik. Proses tersebut diulang sampai didapatkan data lengkap. Dengan purposive, peserta didik yang dapat memberikan informasi yang cukup dan dapat berkomunikaasi dengan baik dijadikan subjek penelitian dengan alasan supaya dapat memberikan informasi yang cukup untuk menjawab tujuan dari penelitian. Dari proses tersebut didapatkan 1 subjek penelitian dari tipe gaya belajar visual (N-12), 1 subjek penelitian tipe gaya belajar auditorial ( $\mathrm{N}-07)$, dan 1 subjek penelitian darai tipe gaya belajar kinestetik (N-14). Teknik analisis data penelitian ini mengacu pada model analisis data dari Miles and Huberman yaitu dilakukan melalui reduksi data, penyajian data, menarik kesimpulan dan memverifikasi kesimpulan

\section{Hasil dan Diskusi}

Penelitian ini menggunakan metode penelitian kualitatif eksploratif dengan instrumen meliputi peneliti itu sendiri serta instrumen pendukung meliputi tes soal kemampuan pemecahan masalah matematik, angket gaya belajar, dan wawancara tidak terstruktur. Hasil dari pemberian tes soal kemampuan pemecahan masalah matematik dengan teknik think aloud didapatkan data kemampuan pemecahan masalah matematik peserta didik. Peserta didik yang dapat menyelesaikan tes soal kemampuan pemecahan masalah matematik diberikan angket gaya belajar supaya dapat diketahui termasuk pada kategori gaya belajar visual, gaya belajar auditorial, dan gaya belajar kinestetik. Kemudian peserta didik dari setiap kategori diwawancarai secara tidak terstruktur sampai didapatkan data berupa informasi yang diharapkan untuk dijadikan subjek penelitian. Berdasarkan kriteria yang diharapkan oleh peneliti, didapatkan subjek penelitian yaitu N-12 dari gaya belajar visual, N-07 dari gaya belajar auditorial, dan N-14 dari gaya belajar kinestetik.

Berikut ini diuraikan hasil penelitian kemampuan pemecahan masalah matematik ketiga subjek N-12, N-07, dan N-14 dalam Tabel 3.1 berikut. 
Tabel1

Kemampuan Pemecahan Masalah Matematik Subjek N-12, N-07, dan N-14

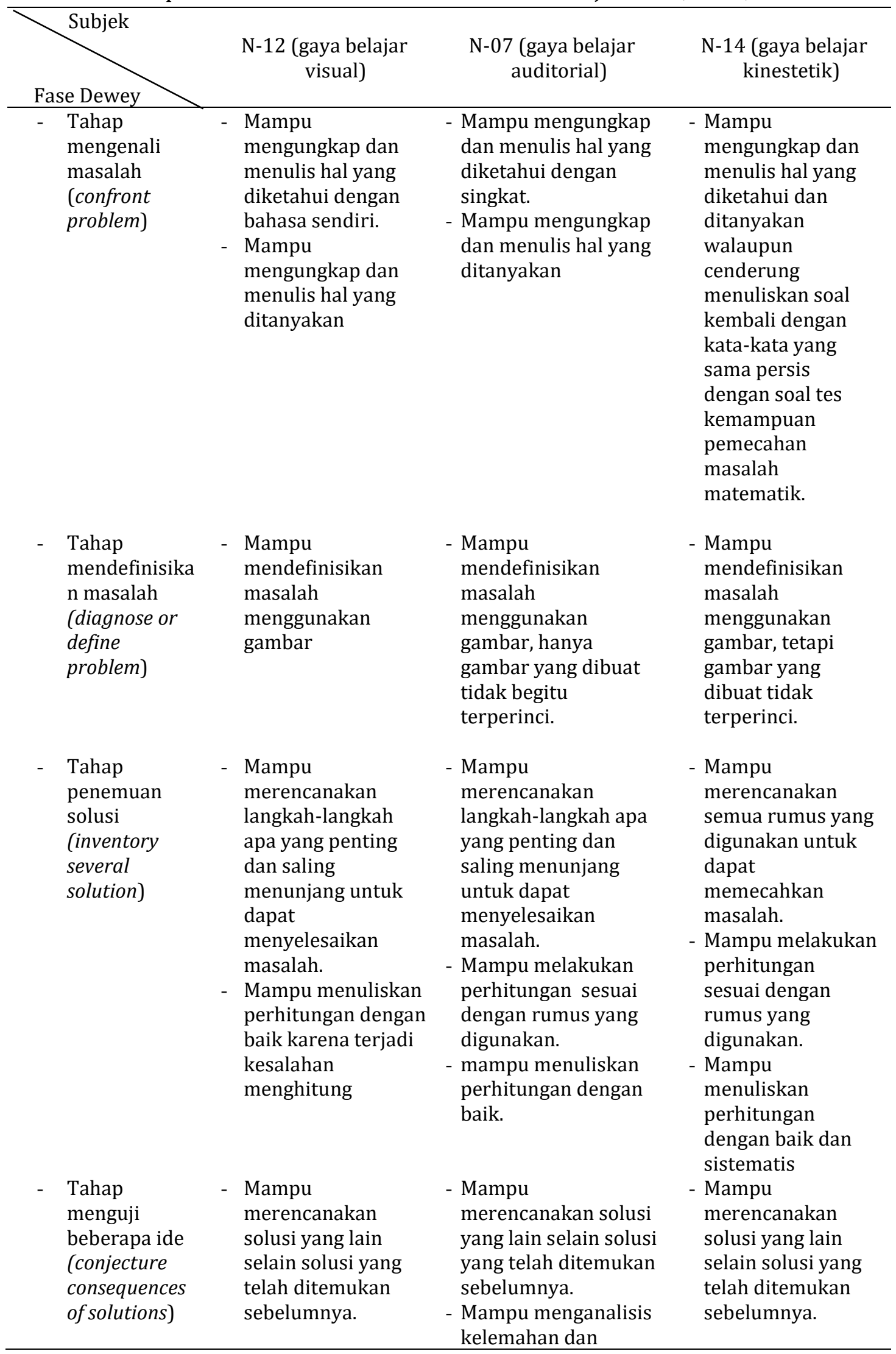




\begin{tabular}{llll}
\hline Tahap & Mampu & kelebihan dari solusi & - Mampu \\
mengambil & menganalisis & yang ditemukan. & menganalisis \\
hipotesis & kelemahan dan & & kelemahan dan \\
terbaik (test & kelebihan dari & & kelebihan dari \\
consequences) & solusi yang & & solusi yang \\
& ditemukan. & & ditemukan. \\
& & & \\
\end{tabular}

Berdasarkan hasil analisis dapat disimpulkan bahwa subjek $\mathrm{N}-12$ tipe gaya belajar visual mampu memecahkan masalah matematik melalui lima tahap menurut John Dewey. Subjek N-07 tipe gaya belajar auditorial dan subjek N-14 tipe gaya belajar kinestetik mampu memecahkan masalah matematik melalui lima tahap menurut John Dewey.Pemaparan hasil penelitian ketiga subjek menurut teori John Dewey materi perbandingan trigonometri ditinjau dari 3 gaya belajar berikut ini:

Subjek N-12 dengan tipe gaya belajar visual, pada tahap mengenali masalah (confront problem) dapat mengidentifikasi kecukupan data untuk memecahkan masalah dengan menuliskan informasi-informasi mengenai hal-hal yang diketahui dan yang ditanyakan. Hasil jawaban peserta didik terlihat pada gambar berikut:

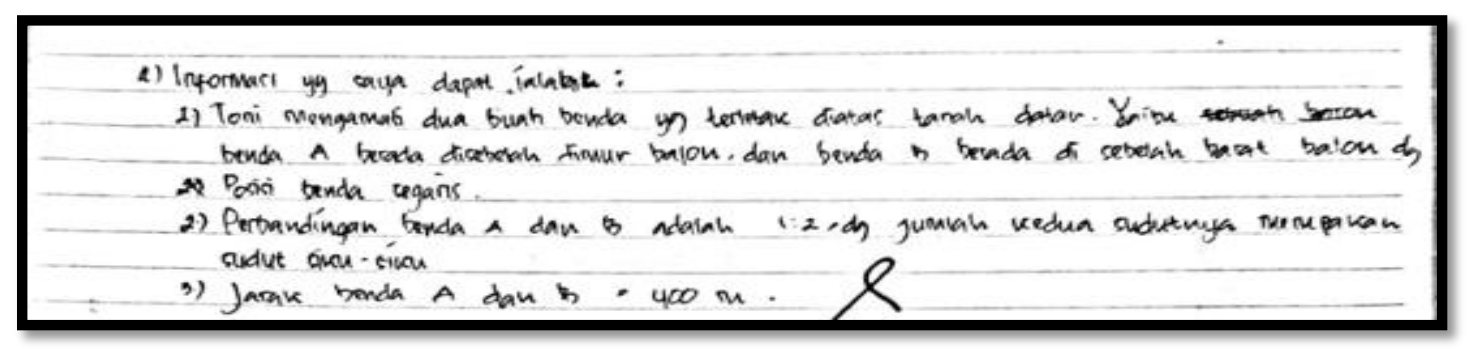

Gambar 1. Tahap Mengenali Masalah Subjek N-12

Pada tahap mendefinisikan masalah ( diagnose or define problem), subjek N-12 dapat membuat sketsa atau gambar untuk memulai rencana penyelesaian soal. Hasil jawaban peserta didik terlihat pada gambar berikut:

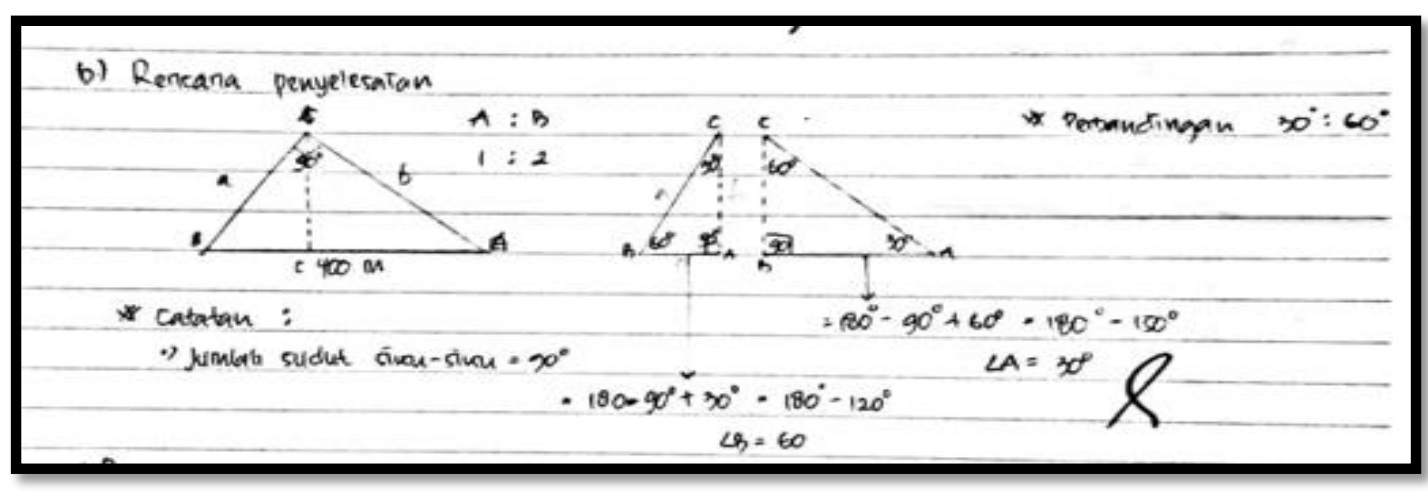

Gambar 2. Tahap Mendefinisikan Masalah Subjek N-12

Hal ini seperti yang dikemukakan oleh Shafie, Janier, \& Ahmad [18] yaitu salah satu media untuk mengkomunikasikan informasi dari peserta didik dengan gaya belajar visual adalah menggunakan gambar. 
Namun pada tahap penemuan solusi (inventory several solution) subjek N-12 gaya belajar visual melakukan perhitungan yang kurang tepat. Kesalahan tersebut dapat dilihat pada Gambar berikut.

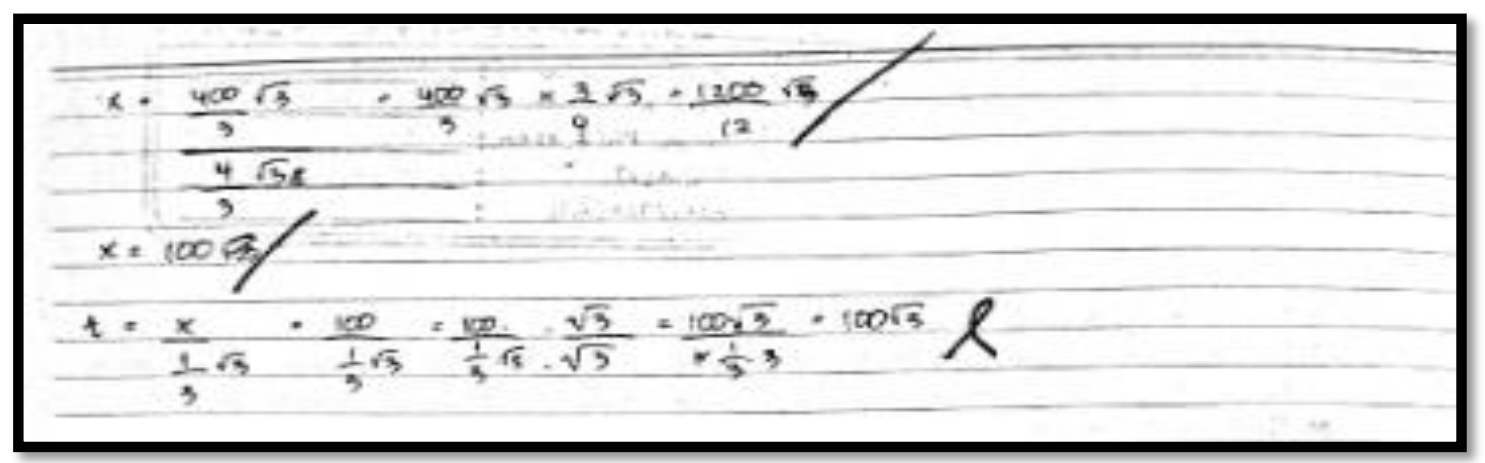

Gambar 3. Tahap Penemuan Solusi Subjek N-12

Kesalahan ini bukan karena $\mathrm{N}-12$ kurang mampu dalam mengoperasikan pembagian bentuk akar tetapi karena kurang teliti dalam melakukan perhitungan, hal ini terlihat pada kemampuan $\mathrm{N}-12$ dalam tahap menguji beberapa ide (conjecture consequences of solutions), subjek N-12 tipe gaya belajar visual mampu merencanakan solusi yang lain selain solusi yang telah ditemukan sebelumnya dan mampu melakukan perhitungan sesuai dengan rumus yang digunakan dengan benar. Terlihat pada hasil jawaban peserta didik berikut:

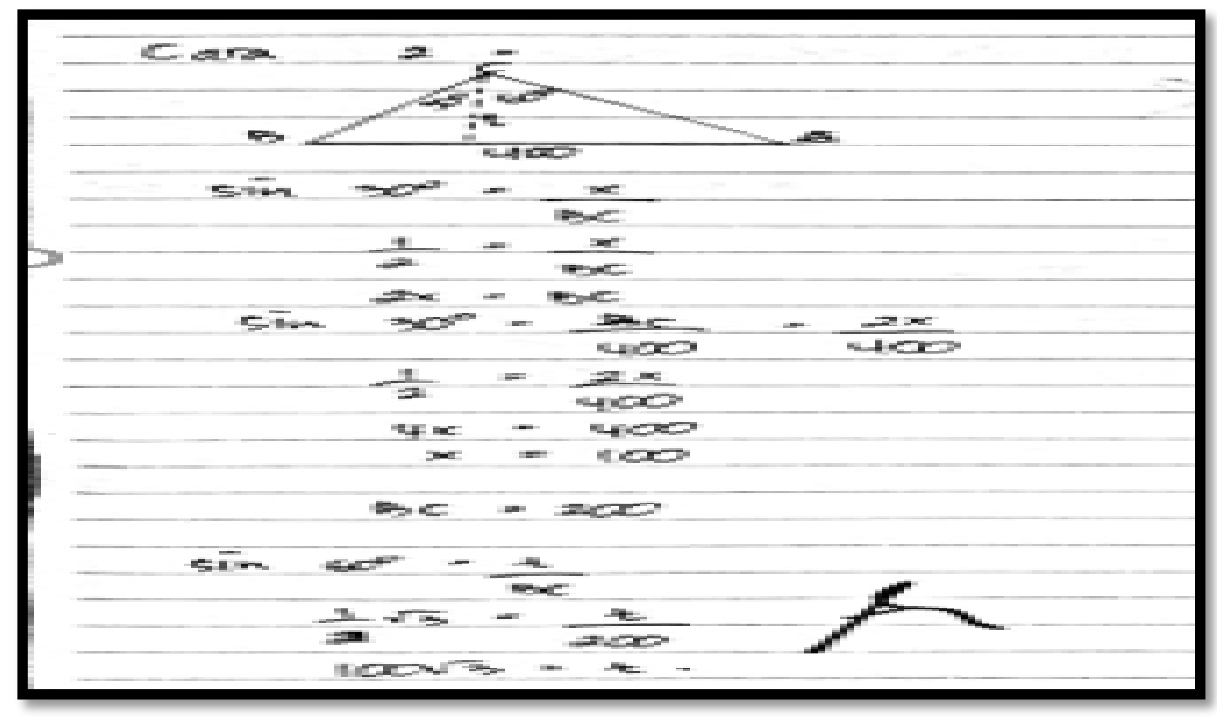

Gambar 4. Tahap Menguji Beberapa Ide Subjek N-12

Tahap mengambil hipotesis terbaik (test consequences), peserta didik dapat menganalisis kelemahan dan kelebihan dari solusi yang ditemukan. Hasil jawaban peserta didik dapat dilihat pada gambar berikut: 


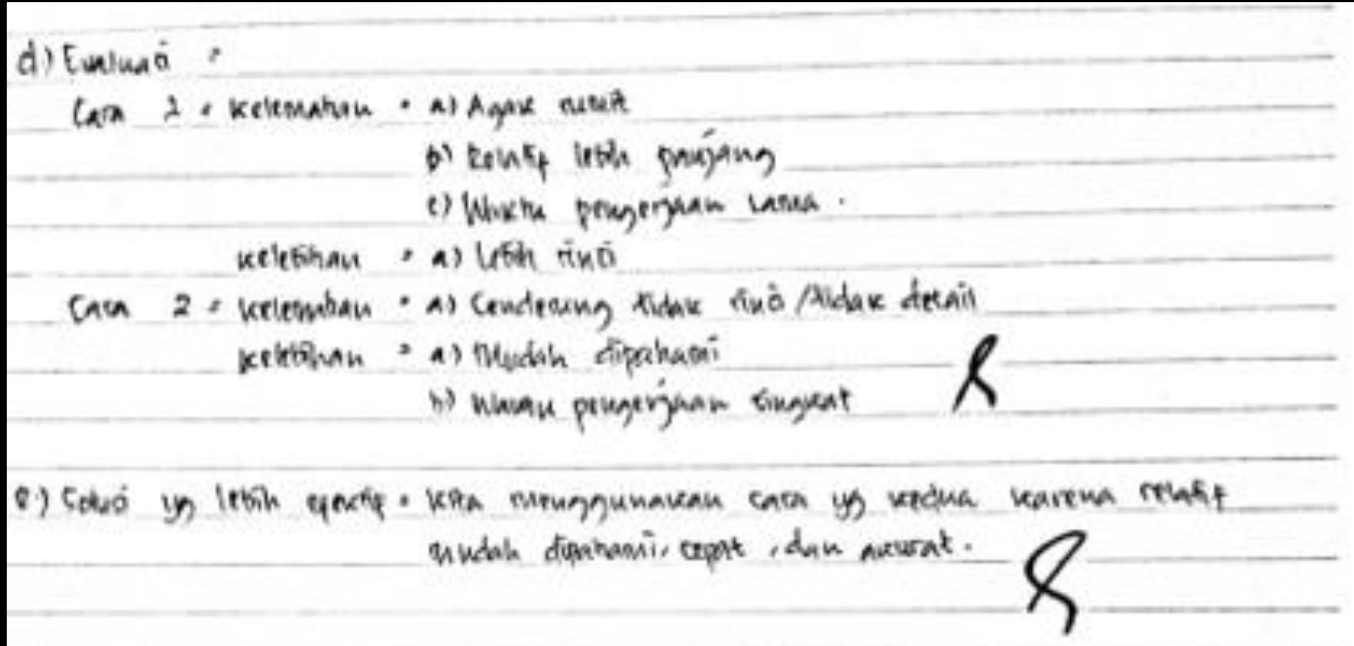

Gambar 5. Tahap Mengambil Hipotesis Terbaik Subjek N-12

Peserta didik dapat menentukan solusi yang terbaik. Pada saat wawancara subjek N-12 tipe gaya belajar visual berbicara sangat cepat. Hal ini sesuai dengan yang dijelaskan oleh DePorter \& Hernacki [19] beberapa ciri-ciri peserta didik yang bergaya belajar visual adalah berbicara dengan cepat.

Subjek N-07 tipe gaya belajar auditorial berdasarkan hasil analisis mampu memecahkan masalah melalui lima tahap pemecahan John Dewey, pada tahap mengenali masalah (confront problem), mampu mengetahui apa saja yang diketahui dan ditanyakan pada soal hanya dengan menuliskan hal yang penting saja. Berikut hasil jawaban peserta didik pada tahap mengenali masalah.

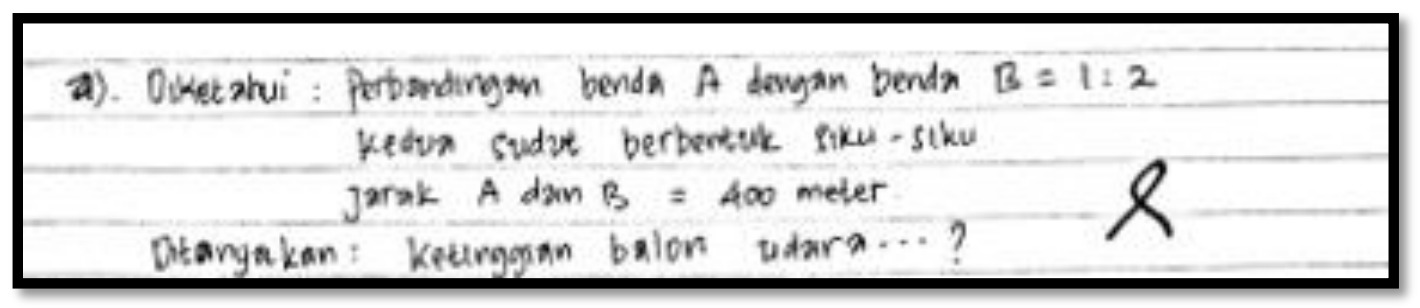

Gambar 6. Tahap Mengenali Masalah Subjek N-07

Pada saat melakukan think aloud subjek N-07 mampu menjelaskan langkahlangkah pengerjaan soal tes kemampuan pemecahan masalah matematik dengan kalimat sendiri dengan lancar. Hal ini seperti yang dikemukakan oleh Depoter \& Hernacki [19] peserta didik auditorial merasa kesulitan dalam menulis tapi hebat dalam bercerita dan pembicara yang fasih. Tahap mendefinisikan masalah (diagnose or define problem) subjek N-07 juga mampu mendefinisikan masalah menggunakan gambar hanya gambar yang dibuat tidak begitu terperinci dan gambar yang dibuat tidak cukup lengkap pada saat dilihat oleh orang lain. Hasil jawaban peserta didik dapat dilihat pada gambar berikut: 


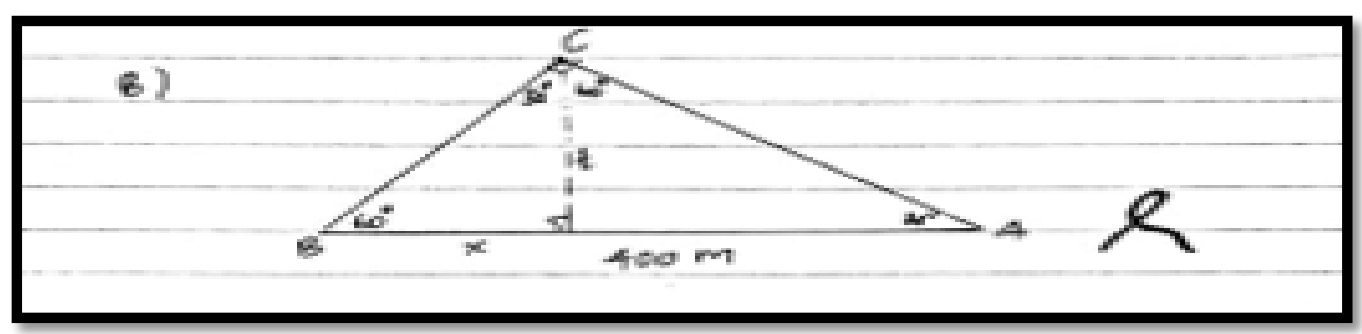

Gambar 7. Tahap Mendefinisikan Masalah Subjek N-07

Hal ini seperti yang dikatakan Boneva \& Mihova [20] peserta didik auditorial mempunyai masalah dengan pekerjaan-pekerjaan yang melibatkan visualisasi. Tahap penemuan solusi (inventory several solution), subjek N-07 tipe gaya belajar auditorial mampu menuliskan perhitungan dengan baik, terlihat pada jawaban peserta didik berikut.

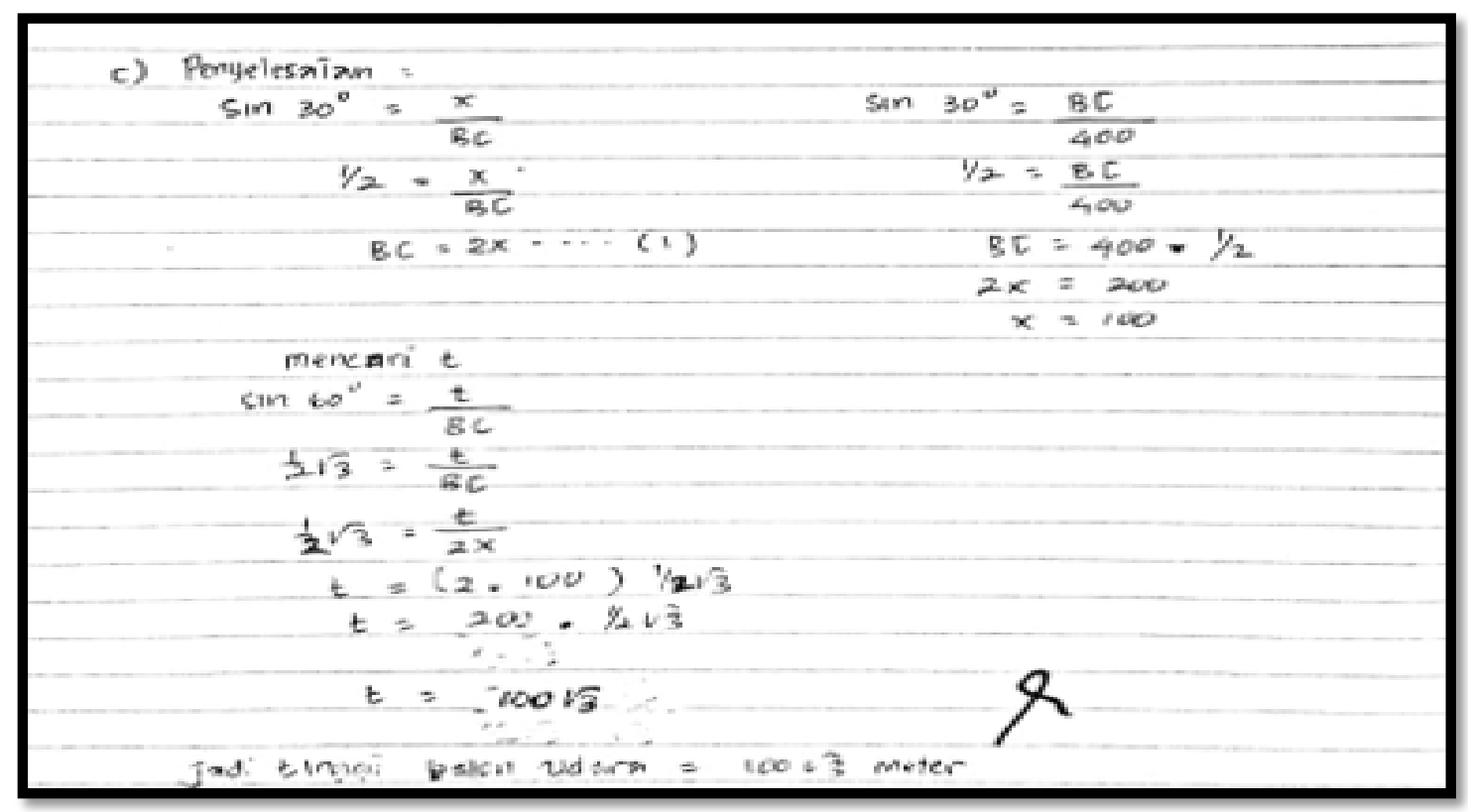

Gambar 8. Tahap Penemuan Solusi Subjek N-07

Kemudian pada tahap menguji beberapa ide (conjecture consequences of solutions), N-07 tipe gaya belajar auditorial mengetahui solusi yang lain. Tahap mengambil hipotesis terbaik (test consequences), subjek $\mathrm{N}-07$ dapat menganalisis kelemahan dan kelebihan dari solusi yang ditemukan.

Subjek N-14 dengan gaya belajar kinestetik mampu memecahkan masalah melalui lima tahap pemecahan John Dewey. Tahap memahami masalah, subjek N-14 tipe gaya belajar kinestetik mampu mengetahui apa saja yang diketahui dan ditanyakan pada masalah walaupun cenderung menuliskan apa yang diketahui dan ditanyakan dengan menulis soal kembali dengan kata-kata yang sama persis. Pada saat mengerjakan soal tes kemampuan pemecahan masalah matematik, subjek N-14 membaca soal dengan menggunakan jari sebagai penunjuk membaca. Hal ini sesuai dengan Deporter \& Hernacki [14] salah satu ciri peserta didik dengan gaya belajar 
kinestetik adalah berbicara dengan perlahan dan menggunakan jari sebagai penunjuk ketika membaca.

Tahap mendefinisikan masalah (diagnose or define problem) peserta didik kinestetik yaitu N-14 juga mampu mendefinisikan masalah menggunakan gambar. Berikut jawaban peserta didiknya.

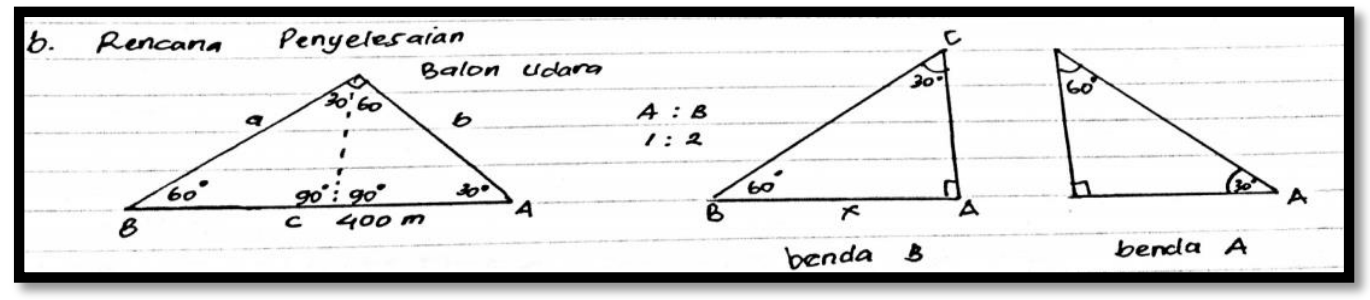

Gambar 9. Tahap Mendefinisikan Masalah Subjek N-14

Tahap penemuan solusi (inventory several solution), subjek N-14 tipe gaya belajar kinestetik mampu menuliskan perhitungan dengan baik dan sistematis. Dan pada tahap menguji beberapa ide (conjecture consequences of solutions), mampu merencanakan solusi yang lain selain solusi yang telah ditemukan sebelumnya. Tahap mengambil hipotesis terbaik (test consequences), subjek N-14 dapat menganalisis kelemahan dan kelebihan dari solusi yang ditemukan.

\section{Simpulan}

Kemampuan pemecahan masalah matematik yang diteliti dalam penelitian ini difokuskan pada kemampuan pemecahan masalah matematik peserta didik gaya belajar visual, gaya belajar auditorial, dan gaya belajar kinestetik. Berdasarkan data kemampuan pemecahan masalah matematik materi perbandingan trigonometri peserta didik yang bergaya belajar visual, memiliki kemampuan menyampaikan argumentasi verbal, mengidentifikasi fakta, melakukan perhitungan dalam menyelesaikan masalah, walaupun tahap penemuan solusi (inventory several solution) melakukan kesalahan pada saat perhitungan, membandingkan jawaban yang didapat dengan perhitungan yang lain, dan memilih strategi yang tepat setelah melakukan percobaan strategi yang lain.

Kemampuan pemecahan masalah matematik materi perbandingan trigonometri peserta didik yang bergaya belajar auditorial, memiliki kemampuan menyampaikan argumentasi verbal, mengidentifikasi fakta dengan membuat gambar hanya gambar yang dibuat tidak begitu terperinci, tidak cukup lengkap pada saat dilihat oleh orang lain. Melakukan perhitungan dalam menyelesaikan masalah, membandingkan jawaban yang didapat dengan perhitungan yang lain, dan memilih strategi yang tepat setelah melakukan percobaan strategi yang lain.

Kemampuan pemecahan masalah matematik materi perbandingan trigonometri peserta didik yang bergaya belajar kinestetik, memiliki kemampuan menyampaikan argumentasi verbal, mengidentifikasi fakta, melakukan perhitungan dalam menyelesaikan masalah, membandingkan jawaban yang didapat dengan perhitungan 
yang lain, dan memilih strategi yang efektif setelah melakukan percobaan strategi yang lain.

\section{Ucapan Terimakasih}

Terimakasih kepada Kepala Sekolah, guru matematika SMK Negeri 1 Banjar Kota Banjar yang telah memberikan ijin dan membantu kelancaran pelaksanaan penelitian. Selain itu, terimakasih kepada peserta didik yang telah bersedia mengisi tes gaya belajar, menjawab soal tes kemampuan pemecahan masalah matematik, dan wawancara.

\section{Referensi}

[1] Arhasy E AR \& Mulyani E 2017 Kontribusi Model Problem Based Learning Berbantuan Media Software Maple Terhadap Kemampuan Berpikir Kreatif Matematis Dan Self Regulated Learning Mahasiswa Jurnal Siliwangi Seri Pendidikan 3(1)

[2] Kemendikbud 2013 Materi Pelatihan Guru Implementasi Kurikulum 2013 (Jakarta: Kementerian Pendidikan dan Kebudayaan)

[3] Aljaberi N M 2015 University Students' Learning Styles And Their Ability To Solve Mathematical Problems International Journal of Business and Social Science 6(4)

[4] Sundayana R 2016 Kaitan Antara Gaya Belajar, Kemandirian Belajar, dan Kemampuan Pemecahan Masalah Siswa SMP dalam Pelajaran Matematika. Jurnal Mosharaf 8(1)

[5] NCTM 2000 Principles and Standards for School Mathematics (USA: The National Council of Teacher Mathematics inc)

[6] Iswadi H 2016 http://www.ubaya.ac.id/2014/content/articles detail/230.

[7] Ariansyah A 2017 Profil Pemahaman Konsep dan Pemecahan Masalah Bilangan Real Ditinjau dari Gaya Belajar Siswa Kelas X Sma Al Bayan Makassar (Tesis: Progam Pascasarjana Pendidikan Matematika Universitas Negeri Makasar)

[8] Awaliyah F 2016 Analisis Kemampuan Pemecahan Masalah Siswa Kelas X Sma Materi Trigonometri Dalam Pembelajaran Model Auditory Intellectually Repetition (Air) https://lib.unnes.ac.id/

[9] Syaharuddin S 2016 Deskripsi Kemampuan Pemecahan Masalah Matematika Dalam Hubungannya Dengan Pemahaman Konsep Ditinjau dari Gaya Belajar Siswa Kelas VIII SMPN 4 Binamu Kabupaten Jeneponto (Tesis: Progam Pascasarjana Pendidikan Matematika Universitas Sebelas Maret, Surakarta)

[10] Carson J 2007 A Problem With Problem Solving: Teaching Thinking Without Teaching Knowledge The Mathematics Educator 17(2) https://www.researchgate.net/publication

[11] Cahyani H \& Setyawati R W 2017 Pentingnya Peningkatan Kemampuan Pemecahan Masalah Melalui PBL Untuk Mempersiapkan Generasi Unggul Menghadapi MEA. Prosiding Seminar Nasional Matematika X 2016 https://journal.unnes.ac.id/sju/index.php/prisma/article 
[12] Sundayana R 2016 Kaitan Antara Gaya Belajar, Kemandirian Belajar, dan Kemampuan Pemecahan Masalah Siswa SMP dalam Pelajaran Matematika Jurnal Mosharafa 8(1)

[13] Jainuri M 2016 Kemampuan Pemecahan Masalah (Online) https://www.academia.edu

[14] Rianto V M, Yusmin E, Nursangaji A 2017 Kemampuan Pemecahan Masalah Siswa Berdasarkan Teori John Dewey Pada Materi Trigonometri Jurnal Pendidikan dan Pembelajaran 6(7)

[15] Andriani T, Suastika K \& Sesanti N R 2017 Analisis Kesalahan Konsep Matematika Siswa Dalam Menyelesaikan Soal Trigonometri Kelas X Tkj Smkn 1 Gempol Tahun Pelajaran 2016/2017 Jurnal Pi: Mathematics Education Journal http://ejournal.unikama.ac.id/index.php/pmej

[16] Sugiyono 2017 Metode Penelitian Pendidikan:(Pendekatan Kuantitatif, Kualitatif Dan $R \& D$ ) (Bandung: Alfabeta)

[17] Susanto 2016 Mengidentifikasi Kesalahan Mahasiswa dalam Membuktikan Teorema- Teorema Kesebangunan Segitiga dengan Metode Think Aload Prosiding Seminar Nasional Unesa: ISBN978-602-449-023-2

[18] Shafie A B, Janier J B \& Ahmad W F B W 2009 Visual Learning in Application of Integration In International Visual Informatics Conference (pp. 832-843) (Springer, Berlin, Heidelberg)

[19] Deporter B \& Hernacki M 2015 Quantum Learning Membiasakan Belajar Nyaman dan Menyenangkan (Bandung: Kaifa)

[20] Boneva D \& Mihova E 2011 Learning Styles And Learning Preferences. Dyslang, Dyslexia \& Additional Academic Language Learning Dyslang Module 8 